\title{
THE FEDERAL FOOD LEGISLATION OF 1938 AND THE FOOD INDUSTRY
}

\author{
Robert W. Austri*
}

I

Between the enactment of the original Federal Food and Drugs Act of $1906^{1}$ and the passage of the Federal Food, Drug, and Cosmetic Act of $1938,{ }^{2}$ amendments to the Ig06 Act were few and far between. While developments in the law came slowly in that period of thirty-two years, the development of the industries affected by the statute was tremendous. The proprietary drug business had expanded beyond belief; the distribution of foodstuffs changed from a general practice of selling foods in bulk to the point where packaged foods had become the rule on shelves of retail grocers. Not only had the food and drug industries expanded and their methods changed, but the making and selling of cosmetics had become an entirely new industry.

In addition to the above mentioned changes in the mechanics of distribution of these products, changes were rapid in the American economic system in the twentyseven years between the passage of the original law and the introduction of the so-called Tugwell Bill in Congress in r933. New technical developments had been attended by new methods of manufacture and distribution of food, drugs and cosmetics. New products were introduced, plant capacity increased, and competition became more difficult to control with the increase of mass production, speedy distribution and the growth of the chain store.

The Department of Agriculture, and particularly the Food and Drug Administration thereof, which was charged with the enforcement of the Federal Food and Drugs Act of Igo6, found itself handicapped not only by the lack of adequate funds to provide for the sinews of war against illegal abuses, but by the fact that the weapon which had been given to it in 1906 to prosecute that war was becoming more and more obsolete as the industries affected progressed both in the production and distribution of their products.

For years the Food and Drug Administration hoped to remedy the legal defects and administrative difficulties inherent in the old law. It was not until the advent of increased interest in the problems of the consumer, which is so definite a part of the

- A.B., 1929, Dartmouth College; LL.B., 1932, Harvard University. Member of the New York Bar. Associated with Breed, Abbott \& Morgan, Attorneys, New York City. Member of the Committee on Federal Legislation of the New York State Bar Association.

234 STAT. 768 (rg06), 21 U. S. C. c. I.

52 STAт. 1040 (1938), 21 U. S. C. A. $\$ \$ 301-392$ (Supp. 1938). 
present National Administration, that the movement for a new law became such as to give the Food and Drug Administration, industry and the public some hope that a new and modern statute would replace the law of 1906.

It is not the province of an article of this kind to discuss in detail the legislative history of the Federal Food, Drug, and Cosmetic Act of x938. Suffice it to say that in the first session of the 73rd Congress in 1933 Senator Copeland introduced the Tugwell Bill prepared under the direction of Dr. Rexford G. Tugwell. This first measure provided for a drastic permit control of factories, for inspection thereof, and, perhaps of most importance, for compulsory grade labeling under which any food whose label failed to bear the required symbol of quality and grade was to be deemed misbranded.

Five years elapsed between the introduction of the Tugwell Bill and the final enactment of the law in $193^{8}$. In that time more than forty bills were introduced in Congress; hearings were held before both Senate and House Committees, and President Roosevelt sent a special message to Congress recommending the passage of new food and drug legislation.

In addition to the natural delays incident to such a complete revision of existing law dealing with so complicated a subject, the final enactment of new legislation was delayed by a controversy between the Department of Agriculture and the Federal Trade Commission concerning which administrative body should have control over the advertising of foods, drugs and cosmetics sold in interstate commerce. When in March of 1938 the Wheeler-Lea Act, ${ }^{3}$ amending the Federal Trade Commission Act, became law increasing the powers of the Federal Trade Commission and giving it specific powers over the advertising of foods, drugs and cosmetics, the last obstruction in the way of complete revision of existing law was removed.

Finally, after a minor controversy on the court review section of the pending bill, the conference report on Senate Bill 5 was agreed to by the Senate and House and was approved by the President on June 25, 1938 as Public Law No. 7x7.

Except for certain administrative provisions, the effective date of the law, in so far as it related to food, was fixed at twelve months from the date of its enactment or June 25, I939. This intermediate period of one year was granted for the purpose of permitting industry to analyze the new statute and its effect upon business, as well as to permit the Secretary of Agriculture and the Food and Drug Administration to take stock, provide, where necessary, new enforcement procedure and to issue rules, regulations and standards provided for in the law.

This article deals with the Food, Drug, and Cosmetic Act and the Wheeler-Lea Act only as they relate to food and is an attempt to show the possible effect of some of their principal provisions upon the food industry.

\section{Definitions and Standards for Food}

Perhaps of most interest to the food industry is Section 4or of the new food law which empowers the Secretary of Agriculture in the interest of consumers, where

52 StAT. III (1938), I5 U. S. C. A. c. 2 (Supp. 1938). 
such action in his opinion will promote honesty and fair dealing, to promulgate regulations establishing for any food under its common or usual name a reasonable definition and standard of identity, a reasonable standard of quality, and reasonable standards of fill of container.

The issuance of standards of identity and standards of quality by the Secretary of Agriculture is not new, but the theory that the Secretary may issue such standards for all food products ${ }^{4}$ giving to them the force of law, thus making foods not labeled in accordance therewith misbranded, is new. Under the old food law, the Secretary of Agriculture has issued both standards of identity and standards of quality. The standards of identity issued by the Secretary were not authorized in the Federal Food and Drug Law of Igo6, nor were they enforceable by the Secretary of Agriculture with respect to any manufacturer or distributor in so far as the labeling of commodities was concerned. In Service and Regulatory Announcement, Food and Drug No. 2, Fifth Revision, November 5, x936, it was specifically stated by the Secretary that the standards of identity contained therein were issued as a guide for the officials of the Department of Agriculture in enforcing the Federal Food and Drugs Act and it was further stated: "They are so framed as to exclude substances not mentioned in the definition, and in each instance they imply that the product is clean and sound."

In its preface to the same Service and Regulatory Announcement, the Department of Agriculture specifically states: "These standards of identity are not to be confused with standards of quality or grade." (Italics added.) An example of a standard of identity such as has been issued by the Secretary is the standard for Farina, appearing in the above Announcement under the heading "Vegetable Products-A. Grain and Flour:

"I2. FARINA. The purified middlings of hard wheat other than durum."

The standards of quality heretofore issued by the Secretary have been issued only since the adoption in 1930 of the McNary-Mapes Amendment ${ }^{5}$ and have been limited to standards of quality for canned food.

The McNary-Mapes Amendment added a section to the misbranding provisions of the old food law and provided that a food would be deemed misbranded "if it be canned food and falls below the standard of quality, condition and/or fill of container, promulgated by the Secretary of Agriculture for such canned food and its package or label does not bear a plain and conspicuous statement prescribed by the Secretary of Agriculture indicating that such canned food falls below such standard." An example of a standard of quality issued under the McNary-Mapes Amendment is the following standard of quality and condition for canned pears:

\footnotetext{
'It should be noted that $\$ 40 \mathrm{r}$ contains a proviso exempting "fresh or dried fruits, fresh or dried vegetables or butter" from the promulgation of standards of identity and standards of quality, except that standards of identity may be established for "avocadoes, cantaloupes, citrus fruits and melons" which relate only to maturity and to the effects of freezing.

" 46 STAT. I0I9 (r930), 21 U. S. C. \$10, "Foods," par. 5.
} 
"22. Standard canned pears are the normally flavored and normally colored canned food consisting of $(I)$ the normal sized, uniform sized, tender, peeled, mature, unblemished, unbroken halves of the fruit of the pear tree from which the calyx end and seed cells have been removed, with or without removal of the internal stem, and (2) sugar solution of sufficient strength, so that the liquid portion of the finished product reads not less than $\mathrm{I}_{4}^{\circ}$ Brix (read at the proper temperature for the instrument used)."

It will be seen that these two types of standard are not necessarily mutually exclusive but that, generally speaking, a standard of identity under the old food law was a definition of a product under its common name which excluded all other types of product therefrom but did not deal with the quality of the product except that it had to be "clean and sound" which, of course, was a requirement for the distribution of any food product under the old law. In other words, under the regulations of the Secretary issuing standards of identity under the old food law, a product was not "Farina" in the eyes of the Food and Drug Administration unless it consisted of the purified middlings of hard wheat other than durum; but the Secretary, if such a product were clean and sound, had no power with respect to the labeling thereof as to quality.

A standard of quality, on the other hand, under the McNary-Mapes Amendment, was one which set forth the condition and quality of the product named, which condition and quality were absolutely necessary for distribution of such product in interstate commerce unless it was to be labeled "Below U. S. Standard."

Under the Federal Food, Drug, and Cosmetic Act of x938, the Secretary of Agriculture is empowered to issue for all food products both standards of identity and standards of quality, but it seems clear from the language of the statute and the legislative history thereof that he may issue only one standard of identity and only one standard of quality for a given food product. The Secretary of Agriculture is, therefore, not empowered under the new law to fix compulsory grades for food products as would have been the case if the Tugwell Bill had become law. He is only empowered to fix a minimum standard of grade and quality for any given food product with which minimum grade any food must conform if it is to be introduced in interstate commerce without being labeled "Below U. S. Standard."

It is in connection with the labeling requirements of the new law that the new power of the Secretary to issue legal standards of identity and standards of quality will have the most immediate effect upon the food industry. Section 403 of the new statute relates to "Misbranded Food." Sections $403(\mathrm{~g})$ and $403(\mathrm{i})$ relate to the labeling of products in connection with which standards of identity either have or have not been prescribed.

Under Section $403(\mathrm{~g})$ a food is to be deemed misbranded if it purports to be or is represented as a food for which a definition and standard of identity has been prescribed unless it conforms to such definition and standard and unless its label bears the name of the food specified in the definition and standard and in so far as it may be required by such regulations the common names of optional ingredients present in such food. 
Under Section 403(i) a food is to be deemed misbranded if it is a product for which a standard of identity has not been prescribed, unless it bears (I) the common or usual name of the food, if any there be, and (2) if it is fabricated from two or more ingredients, unless its label bears the common or usual name of each such ingredient, except that spices, flavorings and colorings, other than those sold as such, may be designated as spices, flavorings and colorings without naming each. This section requiring a statement of ingredients in cases of fabricated foods is modified by a proviso to the effect that if compliance with it is impracticable or results in deception or unfair competition, exemptions shall be established by regulations promulgated by the Secretary.

It will not be difficult for the food industry to conform to the provisions of Section $403(\mathrm{~g})$, for if a manufacturer or distributor of a food product for which a standard of identity has been promulgated knows what the law requires such food product to consist of, he can, if a manufacturer, see that his product complies therewith, or, if a distributor, secure a guaranty from the manufacturer to the effect that the product complies therewith.

On the other hand, compliance with the provisions of Section 403(i) may result in great difficulty for the food industry. Under the old food law, an article of food which did not contain any added poisonous or deleterious ingredients was not to be deemed adulterated or misbranded if it was a mixture or compound sold under its own distinctive name if the name was accompanied on the same label or brand with a statement of the place where the article had been manufactured or produced. Section 403 (i) of the present law takes the place of this section in the old statute, so that many fabricated foods which were, practically speaking, exempt from the old food law because sold under their own "distinctive names" will now be required to bear the common or usual name of each ingredient on their labels unless they are to be deemed misbranded.

It is true that Section 902(a) (2) of the new food law authorizes the Secretary of Agriculture to designate, prior to June 25, 1939, foods having common or usual names and to exempt such foods from the provision of Section 403(i) (2), requiring statements of ingredients on labels of fabricated foods, pending promulgation of standards of identity therefor. I do not believe that this section will be of much help to manufacturers or distributors of fabricated foods sold under their own distinctive names. Such products might be said to have common or usual names within the meaning of Sections 403(i)(2) and g02(a)(2), but I doubt if the Secretary will feel that he can issue standards of identity therefor. It seems probable to me, therefore, that manufacturers and distributors of most fabricated foods will have to have statements of ingredients on labels by June 25 , 1939, when Section 403 (i) takes effect, unless their products fall within the scope of regulations issued by the Secretary under the power conferred on him by a proviso to the section to establish exemptions where such labeling would be impracticable or would result in deception or unfair competition. It would seem, therefore, that if a manufacturer or distributor believes that 
certain of his food products are not subject to a definition or standard of identity he should urge the early promulgation by the Secretary of such regulations so that he may determine prior to June 25, 1939, whether or not he can secure exemption for such foods from Section 403 (i).

Congress obviously recognized the fact that in some cases the requirement as to the naming of ingredients would be unfair, but unless a manufacturer or distributor of food products may know within a reasonable time whether or not his fabricated foods are subject either to exemption or to the issuance of a standard of identity it may well be that he will be required to state the ingredients thereon by reason of the law's becoming effective before the scope of the exemption is defined. ${ }^{B}$

When a statement of ingredients will be deemed "impracticable" or such as to result "in deception or unfair competition" is a matter of guesswork.7 Assuming that either of these conditions exists with respect to a specified food product, I believe that the exemptions granted by the Secretary under regulation may very well consist of a blanket exemption from the naming of ingredients on labels if a manufacturer of a fabricated food product sold under its own "distinctive name" is willing_to file a list of his ingredients with the Secretary. Such procedure would adequately safeguard the public and the consumer and would not force manufacturers to reveal to their competitors a statement of the ingredients in their product which, as Congress recognized, might result in unfair competition.

Under Chapter 7 of the new statute relating to general administrative provisions, the Secretary is required to hold public hearings prior to the issuance of regulations issued under certain sections of the statute. All other regulations to be issued by the Secretary may be issued without public hearing. Thus, the Secretary may not issue a definition or standard of identity for any food product without public hearing, so that manufacturers and distributors of food products should follow closely notices of the Department with respect to hearings on such standards. On the other hand, regulations under Section 403(i), exempting from disclosure of ingredients those

The time problem is especially acute for but approximately six months remain before the effective date of the statute and manufacturers and distributors of food products as a general rule purchase their label requirements about twelve to eighteen months in advance. Most manufacturers and wholesalers have been advised to buy labels in small lots until regulations have been issued but such advice will not save the situation if regulations with regard to exemption from $\$ 403$ (i) are not fortheoming.

${ }^{7}$ It is most difficult to state types of food which would require the protection of exemption from $\$ 403$ (i). The "impracticable" basis for exemption might apply to packages of assorted fabricated food products in which case a statement of ingredients of all the products contained in the assortment could not possibly be placed upon the package thereof. The "deception or unfair competition" basis for exemption is, in my opinion, to be applied to so-called proprietary products. This view is borne out by the following quotation from the Conference Report on S. 5 in the "Statement of the Managers on the Part of the House":

"Label disclosure of ingredients of food.-The House amendment and the bill as agreed to in conference require the labels of all food products, for which no definition and standard of identity have been prescribed and which are made from two or more ingredients, to bear the names of each ingredient, except spices, flavorings, and colorings, unless exempted by regulations on the ground that compliance is impracticable or results in deception or unfair competition. The conference agreement omits a provision of the House amendment which exempted also proprietary products, when label disclosures would give competitors information they could not otherwise obtain, on condition that the composition had been disclosed to the Secretary." H. R. REP. No. 2716, 75th Cong., 3d Sess. (1938) 23. 
fabricated foods where revealing such ingredients is either "impracticable" or might result "in deception or unfair competition," may be issued by the Secretary without public hearing and may be immediately effective. However, I believe that the policy of the Department of Agriculture will be, wherever possible, to discuss proposed regulations with the industry and to give the industry a proper opportunity to express its views with respect thereto. ${ }^{8}$

Section $403(\mathrm{~h})$ of the new law relates to the labeling of food products for which standards of quality or standards of fill of container have been prescribed by regulations issued by the Secretary. Under this section, if a food purports to be or is represented as a food for which a standard of quality has been prescribed by the Secretary, it will be deemed misbranded if its quality falls below the standard unless its label bears in such manner and form as the regulations specify a statement that it falls below the standard. Food will likewise be deemed misbranded if one for which a standard of fill of container has been prescribed and if it falls below such standard without the label bearing a statement to that effect. It should be noted that the Act does not require the promulgation of standards of quality by the Secretary within any given period of time. The task of issuing standards of quality for all food

- On Wednesday, December 28, 1938, subsequent to the completion of this article, the Secretary of Agriculture issued regulations for the enforcement of the Federal Food, Drug, and Cosmetic Act. The regulation with relation to exemption from the requirement of stating ingredients upon the labels of fabricated foods reads as follows:

"(c) (I) A food shall be exempt from the requirements of clause (2) of section 403(i) of the Act if all words, statements, and other information required by or under authority of the Act to appear on the label of such food, cannot, because of insufficient label space, be so placed on the label as to comply with the requirements of section 403 (f) of the Act and regulations promulgated thereunder. But such exemption shall be on the condition that, if the omission from the label of the statement of the quantity of the contents affords sufficient space to state legibly thereon all the information required by such clause (2), such statement of the quantity of the contents shall be omitted as authorized by regulation (m) (2) under section 403 (c) of the Act, and the information required by such clause (2) shall be so stated as prominently as practicable even though the statement is not of such conspieuousness as to render it likely to be read by the ordinary individual under customary conditions of purchase.

"(2) In the case of an assortment of different items of food, when variations in the items which make up different packages packed from such assortment normally occur in good packing practice, and when such variations result in variations in the ingredients in different packages, such food shall be exempt from compliance with the requirements of clause (2) of section 403 (i) of the Act with respect to any ingredient which is not common to all packages. But such exemption shall be on the condition that the label shall bear, in conjunction with the names of such ingredients as are common to all packages, a statement in terms which are as informative as practicable and which are not-misleading, indicating that other ingredients may be present."

It is obvious from a study of the above quoted exemption contained in the regulations of the Secretary that only one of the bases for exemption has so far been considered by the Department of Agriculture; that is an exemption based on the impracticability of stating ingredients upon the labels of such food products. Both of the exemptions are based upon the lack of space on the label for the statement of ingredients. In footnote 7 , supra, I pointed out that this might well be the "impracticable" basis for exemption fixed upon by the Secretary, but no basis for exemption is contained in the regulations on the theory that to reveal the ingredients of any food product would result in "deception or unfair competition." I, therefore, feel that the advice contained in the body of this article, that manufacturers and distributors should urge the carly promulgation by the Secretary of regulations exempting such food products from a statement of ingredients because of unfair competition, is, if anything, more pertinent today than it was when this article was written. One of the bases for exemption has not been covered in the Secretary's regulations and in fairness to industry it should be so covered as soon as possible, so that on June 25, 1939, manufacturers and distributors of fabricated food may know that their products are correctly labeled and whether or not such products are required to bear 2 statement of ingredients under $\$ 403(i)(2)$. 
products is obviously tremendous and the food industry should bear in mind that standards of quality do not affect it until actually promulgated by the Secretary and that such standards cannot be issued without the specific procedure prescribed by Section 701 (e) of Chapter 7 of the statute. Thus, no standard of quality may be issued without public hearing and the opportunity being given members of the industry to express their views with respect thereto.

It also should be remembered that under the statute as finally enacted it is specifically provided that if any "actual controversy" exists as to the validity of any order (which would include an order setting forth a standard of quality) issued by the Secretary, any person who will be adversely affected by such order may at any time prior to its effective date, i.e., ninety days after its issuance, file a petition with the Circuit Court of Appeals for the circuit in which he resides or his principal place of business exists, for a judicial review of the order.

The Circuit Court of Appeals is empowered to modify or affirm or set aside in whole or in part an order of the Secretary. It is, however, provided that "the findings of the Secretary as to the facts, if supported by substantial evidence, shall be conclusive." It is interesting to note in this connection that in sections providing for review by the Circuit Courts of orders of the Federal Trade Commission and the National Labor Relations Board the respective statutes provide that findings of fact if supported "by evidence" shall be conclusive, the word "substantial" not appearing in such laws. The courts in construing the Federal Trade Commission Act and the National Labor Relations Act have been inclined to read into such statutes the word "substantial," and it would appear here as if Congress in using the word "substantial" in the court review sections of the new food law had forestalled the courts in so doing. ${ }^{9}$

Another interesting point is that Section $\operatorname{Or}(f)(6)$ of the new food law provides:

"The remedies provided for in this subsection shall be in addition to and not in substitution for any other remedies provided by law."

This section is of especial interest in connection with the issuance of standards of quality when one remembers that under the McNary-Mapes Amendment of the old food law, the courts restricted the powers of the Secretary to issue standards of quality by considering the reasonableness of the standards issued.

In I93I, the Department of Agriculture issued regulations concerning canned peas. Revised regulations were issued in May of 1932 to the effect that it was the opinion of the Department that canned soaked dry peas belonged to the class called

\footnotetext{
'In connection with the conclusiveness of findings of fact and the requirement of public hearings, the following cases should be of interest to a student of the new food law: Federal Trade Comm'n v. Curtis Publishing Co., 260 U. S. 568 (1923); Federal Trade Comm'n v. Pacific States Paper Trade Ass'n, 273 U. S. 52 (1927); Federal Trade Comm'n v. Algoma Lumber Co., 29 I U. S. 67 (1934); Florida v. U. S., 292 U. S. I (1934); St. Joseph's Stock Yards Co. v. U. S., 298 U. S. 38 (I936); Morgan v. U. S., 298 U. S. 468 (1936); Washington etc. Coach Co. v. Nat. Labor Relations Bd., 301 U. S. 142 (1937); Federal Trade Comm'n v. Standard Education Society, 302 U. S. II2 (1937); Morgan v. United States, 304 U. S. I (1938); Nat. Labor Relations Bd. v. Mackay Radio \& Tel. Co., 304 U. S. 333 (x938); Consolidated Edison Co. v. Nat. Labor Relations Bd., 59 Sup. Ct. 206 (1938).
} 
"canned peas" and that, being mature, they were substandard and would have to bear the substandard legend if they were to be introduced in interstate commerce without being deemed misbranded. The regulations provided that the following statement, "Below U. S. Standard, low quality, but not illegal, soaked dry peas," must be placed upon the label of all such products.

This ruling very seriously affected the Morgans, who were engaged in the canning business in Indiana and who had developed a tremendous business in the sale of peas matured upon the vine, soaked in water so as to render them tender and palatable, and sold in cans upon which was inscribed in plain language the fact that the product therein was prepared from dry peas. The Morgans went into equity and brought an action against Val Nolan, United States Attorney for the Southern District of Indiana, seeking in the bill of complaint to enjoin him from the enforcing of the Department of Agriculture's regulations against the Morgans and their product prepared from dry mature peas. The Morgans contended that the regulations were invalid because they were unreasonable, arbitrary, and unauthorized under the provisions of the McNary-Mapes Amendment, and also contended that the Food and Drugs Act as amended by the McNary-Mapes Amendment violated the Fifth Amendment of the Constitution of the United States, in that it took plaintiffs' property without due process and without just compensation. They further contended that the law as amended violated the Sixth Amendment of the Constitution, in that no standard of guilt or of liability to seizure was set up in the statute ascertainable from the statute itself, but that guilt or liability to seizure was made dependent upon "reasonable" standards which might be established by the Secretary of Agriculture.

The court stated ${ }^{10}$ that if the provisions in question could be found unreasonable and inconsistent with the Act itself, it would not be necessary for the court to consider the constitutionality of the McNary-Mapes Amendment. The court then found that the Department of Agriculture could not claim that mature dry peas, as processed by the Morgans, did not constitute a wholesome and a pure food. It stressed the purpose of the statute to protect the consumer and to inform purchasers of what they were buying. It found that the purchaser could not be misled when the label, as that of the Morgans, contained the plain statement that the contents were prepared from dry peas.

The court further found that the use of the legend required by the regulations would do irreparable injury to the Morgans for which there was no adequate remedy at law, and it, therefore, ordered that an injunction be issued enjoining the United - States Attorney from enforcing the regulations.

This case was appealed to the Circuit Court of Appeals for the Seventh Circuit which affirmed the order of the District Court and also found no reasnc to consider' the constitutionality of the McNary-Mapes Amendment. ${ }^{11}$

\footnotetext{
${ }^{10}$ Morgan v. Nolan, 3 F. Supp. $1_{43}$ (S. D. Ind. 1933).

"Nolan v. Morgan, 69 F. (2d) 47 I (C. C. A. 7th, 1934).
} 
No later cases contesting the constitutionality of the McNary-Mapes Amendment have been decided by the courts and it is apparently the opinion of the solicitors of the Department of Agriculture that there is no question as to the constitutionality of such a delegation of power. Congress has, therefore, approved the extension of the powers of the Secretary to the point where under the new statute he may prescribe standards of quality for all food products. ${ }^{12}$ It would seem that under the new statute, and particularly the court review sections thereof, the members of the food industry will have the opportunity to protect themselves, as did the Morgans under the old food law, if the standards of quality promulgated by the Secretary under the new law are, unreasonable and arbitrary.

\section{Labezing and Advertising}

The passage of the new Federal Food, Drug, and Cosmetic Act shortly after the passage of the Wheeler-Lea Act, amending the Federal Trade Commission Act, in March of 1938 changes considerably the problems of the food industry with regard to the labeling and advertising of food products.

Under the old Food and Drugs Act of 1906, Section 8 provided that a food would be deemed misbranded:

"Fourth. If the package containing it or its label shall bear any statement, design, or device regarding the ingredients or the substances contained therein, which statement, design, or device shall be false or misleading in any particular." (Italics added.)

The entire emphasis of the old Food and Drugs Act was upon the protection of the consumer. On the other hand, the original Federal Trade Commission Act, when adopted in 1914, was a sort of third arm of the anti-trust laws and the entire purpose of the original Federal Trade Commission Act was the same as the purpose of the anti-trust laws, to protect competitors in business-there was no thought of the consumer at all.

Under the old Food and Drugs Act of 1906, the powers of the Food and Drug Administration were limited to statements false "in any particular" on labels of foods and drugs. The term "label" was defined so as to include any printed matter accompanying the food or drug product when delivered to the consumer.$^{18}$ In other words, the powers of the Food and Drug Administration did not extend to advertising media other than labels on packages or circulars which were included in the package when sold. It is obvious, however, that there was a definite control over a certain type of advertising, which may be called "point of sale" advertising, in the old Food and Drugs Act, although the scope of such control was strictly limited.

Under the original Federal Trade Commission Act, there was nothing in that statute which gave to the Federal Trade Commission, in specific language, any control over false advertising, but it was soon determined that false advertising came within the fundamental intent of the statute as expressed in Section 5 as follows:

22 With the few exceptions noted, supra note 4 .

21. U. S. Dep't Agr., Regulattons for the Enforcement of the Federal Food and Drugs Act (10th Rev. 1930) Reg. I4(a). 
"The Commission is hereby empowered and directed to prevent persons, partnerships or corporations ... from using unfair methods of competition in commerce."

False advertisements were considered "unfair methods of competition" and so were brought within the meaning and the scope of the original Federal Trade Commission Act.

So from Igr4 to $193^{8}$ the advertising and labeling of foods and drugs were controlled by two statutes which were not integrated at all from the administrative point of view. It was partially with the idea of increasing the efficiency of control over advertising that plans were laid for amending both the Food and Drugs Act of rgo6 and the Federal Trade Commission Act of Igr4.

It is well known that there was considerable difficulty during the legislative history of the new food law in determining which administrative body should have control over the advertising of foods, drugs, cosmetics and devices. The controversy was resolved by Congress which lifted out of the then pending Federal Food, Drug, and Cosmetic Bill those provisions relating to the false advertising of such products and put them into one of the pending bills amending the Federal Trade Commission Act.

The result is that the Federal Trade Commission now is given specific control over the advertising of these products and, in addition, by reason of the outlawing of "unfair or deceptive acts or practices in commerce," has the power to take the consumer approach to advertising. The Food and Drug Administration controls the same advertising media that were controlled by it under the old Food and Drugs Act, but is now empowered to prevent manufacturers and distributors of food products from failing to state things on labels and in circulars necessary for the protection of the consumer.

Section 403(a) of the new Act provides that a food shall be deemed to be misbranded.

"(a) If its labeling is false or misleading in any particular."

Sections $201(m)$ and $201(n)$ of the new Act read as follows:

"(m) The term 'labeling' means all labels and other written, printed, or graphic matter (I) upon any article or any of its containers or wrappers, or (2) accompanying such article.

"( $n$ ) If an article is alleged to be misbranded because the labeling is misleading, then in determining whether the labeling is misleading there shall be taken into account (among other things) not only representations made or suggested by statement, word, design, device, or any combination thereof, but also the extent to which the labeling fails to reveal facts material in the light of such representations or material with respect to consequences which may result from the use of the article to which the labeling relates under the conditions of use prescribed in the labeling thereof or under such conditions of use as are customary or usual."

Section I5 of the Wheeler-Lea Act reads as follows:

"Sec. 15. For the purposes of sections I2, I3, and I4-

"(a) The term 'false advertisement' means an advertisement, other than labeling, which is misleading in a material respect; and in determining whether any advertisement 
is misleading, there shall be taken into account (among other things) not only representations made or suggested by statement, word, design, device, sound, or any combination thereof, but also the extent to which the advertisement fails to reveal facts material in the light of such representations or material with respect to consequences which may result from the use of the commodity to which the advertisement relates under the conditions prescribed in said advertisement, or under such conditions as are customary or usual. No advertisement of a drug shall be deemed to be false if it is disseminated only to members of the medical profession, contains no false representation of a material fact, and includes, or is accompanied in each instance by truthful disclosure of, the formula showing quantitatively each ingredient of such drug:"

It will be seen that the language of the comparable sections of the two statutes is almost identical.

We now have two federal statutes relating to misrepresentation of food; the new Food, Drug, and Cosmetic Act giving the Food and Drug Administration very stringent, very broad powers over representations on labels and in circulars sold with the product; the Federal Trade Commission Act, as amended, giving the Federal Trade Commission similar powers over all other types of advertising used in connection with food products.

Two problems of intense interest to the food industry are raised by these facts:

r. It should be noted that the Food and Drug Administration's power over misrepresentation of food, limited in scope as it is, is nevertheless more stringent than is that of the Federal Trade Commission. Section 403(a) of the new food law retains the language of the old food law and provides that a food shall be deemed misbranded if its labeling is false or misleading in any particular (italics added). Section I5 of the Federal Trade Commission Act defines the term "false advertisement" as one which is misleading "in a material respect" (italics added).

2. Both enforcement bodies are charged with the determination as a question of fact of "the extent to which the labeling (advertisement) fails to reveal facts material in the light of such representations or material with respect to consequences which may result from the use of the article (commodity) to which the labeling (advertisement) relates under the conditions prescribed."

It seems obvious that the position of the industry with respect to its labeling and advertising will be most difficult if there is not some coordination between the two administrative bodies. For instance, a statement in advertising might be held not to be misleading in a material respect by the Federal Trade Commission where the same statement on a label or in a circular sold with the merchandise might well be held to be misleading in some way by the Food and Drug Administration and therefore to be deemed a misbranding under the phrase "misleading in any particular." Second, that which the Food and Drug Administration held not to be a vital failure to reveal facts material to the use of a product might, in an advertisement, be held under the Wheeler-Lea Act to be a vital failure to reveal such facts and therefore false advertising and an unfair and deceptive act or practice under the Federal Trade Commission Act, as amended. Unless the food industry can be assured in some way 
that there will be some similarity of approach to these problems, the job of the man in any business charged with preparation of labels and control of advertising will be such as to require the wisdom of a sage.

Here, it is well, I believe, to mention that the new food law, Section 403(j), provides that a food shall be deemed to be misbranded if it purports to be or is represented for special dietary uses unless its label bears such information concerning its vitamin, mineral and other dietary properties as the Secretary determines to be and by regulation prescribes as necessary in order fully to inform purchasers as to its value for such uses.

Let us assume a case where a manufacturer or distributor of a dietary food com. plies with the regulations of the Secretary of Agriculture as to matters necessary in order fully to inform purchasers as to its value for dietary use. Such a manufacturer, under the definition of the term "false advertising" in the Wheeler-Lea Act, might be held by the Federal Trade Commission, using precisely the same material in his advertising as was required by the Food and Drug Administration, to have failed to reveal facts material under the conditions of use prescribed in the advertisement. Industry should, without question, make every attempt to urge the Food and Drug Administration and the Federal Trade Commission to coordinate their views with regard to the advertising and labeling of food products.

On November 29, 1938, W. T. Kelley, Chief Counsel for the Federal Trade Commission, addressed the Associated Grocery Manufacturers of Amercia at The Waldorf Astoria Hotel in New York. In that address he facetiously said:

"Further, food isn't just food any more. You know, it used to be that food was just something to satisfy hunger, to keep you from getting too hungry before the next meal time rolled around. But today, with the doctors finding such close connection between diet and health, both in preventing ailments as well as correcting them, and with the food manufacturers making such therapeutic claims for their products, it is difficult for one to determine, when he dines, whether he is taking a dose of food or eating a remedy." (Italics added.)

It seems to me that this comment, no matter how facetiously intended, expresses a very real problem for the food industry under these statutes.

\section{Emergency Permit Control}

In I933 when the original Tugwell Bill was introduced, it contained a drastic provision to the effect that the Secretary of Agriculture might issue regulations controlling the manufacture and packing of all food products when the conditions surrounding manufacture might result in such products being injurious to health, and their injurious nature could not be adequately determined after the products had entered interstate commerce. The Secretary was authorized to require manufacturers and packers to obtain a permit to operate their plants and to comply with the conditions contained in such permit. If the Secretary decided to revoke or suspend such permit, the manufacturer in question lost his right to ship the food product packed by him in interstate commerce. Among other grounds for suspension of a permit 
was the refusal to permit the inspection of the factory. This plan for control of the manufacture and packing of food products was analogous to that contained in Senator O'Mahoney's. pending Federal Corporation Licensing Bill which would require a license to do business in interstate commerce, the revocation of which would suspend the right of the licensee to do an interstate business.

The permit control feature of the Tugwell Bill was violently attacked and in subsequent bills during the five-year period of incubation of the new food law its terms were considerably modified.

In the measure as enacted, the Secretary's powers are limited by the requirement that he find the class of food governed by permit may become injurious to health "by reason of contamination with micro-organisms during the manufacture, processing or packing thereof," as well as, by the requirement that he find the injurious nature of the food cannot be adequately determined after such article has entered into interstate commerce. Furthermore, it will be noted that the emergency permit control is for a "temporary period of time" and that such control may be imposed upon the class of food in question "in any locality." It does not appear probable, therefore, that the Emergency Permit Control section of the new statute will permit of any broad application of the section to all manufacturing and processing of food products.

After the issuance of emergency regulations under this section, no person can introduce into interstate commerce any food product produced or handled in such locality unless the manufacturer, processor or packer producing such products in such locality holds a permit issued by the Secretary. The Secretary is authorized to suspend any permit if he finds that the conditions thereof have been violated, and any officer or employee designated by the Secretary is given access to any establishment, the owner of which holds a permit, for the purpose of ascertaining whether or not the conditions of the permit are being complied with. Failure to allow such inspection is a basis for revocation of the permit.

It will be seen that this emergency permit control of places of manufacture of food products is much narrower and less drastic than was the original provision in the Tugwell Bill, although the amount of power delegated to the Secretary of Agriculture herein is in fact as broad as any power delegated to the Secretary under the statute and can become the power, in certain instances, to license interstate food business.

In connection with emergency permit control, it should be remembered that Section 704 of the statute provides that, for purposes of enforcing the law, officers or employees duly designated by the Secretary "after first making request and obtaining permission of the owner" are authorized to enter "at reasonable times" any factory, warehouse, establishment or vehicle in which foods are manufactured, processed, packed or held and to inspect at such times such factory, warehouse, establishment, vehicle, all pertinent equipment, finished and unfinished materials, containers and labeling. Curiously enough, while Section 704 provides that the Secretary, before entering a factory for the purpose of inspecting the same, must secure the permission 
of the owner thereof, Section $301(f)$ of the statute relating to penalties makes it a crime to refuse such permission.

I believe that the inspection of factories under powers granted in Section 704 will provide information upon the basis of which permits will be required under the Emergency Permit Control section of the law.

\section{Effective Datr and Repeats}

It should be borne in mind that Section 902 of the Act specifically provides that the Food, Drug, and Cosmetic Act of 1938 takes effect twelve months after the date of its enactment and that the Federal Food and Drugs Act of rgo6, as amended, remains in force until such date but is "repealed effective upon such date." On June 25, 1939, therefore, the old food law automatically dies and with it die all of the regulations thereunder. On the same day the new law rises, so to speak, from the ashes of the old and it is up to the Secretary of Agriculture, under Section 70 r relating to regulations and public hearings, which became effective on June $25,193^{8}$, so to clothe the new statute with regulations as to make it possible for the food industry to continue in business without any hitches or difficulties on the day that the transition from the old law to the new law takes place. It, therefore, behooves all members of the food industry in all branches of the industry to study the provisions of this new law and to cooperate as much as possible with the Department of Agriculture in the evolution of new regulations under the new statute. 